\title{
En Relación con la Novela como Proceso o Ciclo de Vida
}

Literature is not enough Katerine MaNsfield

Según señales no demasiado explícitas de algunos allegados, la alqui. mia (como otra de las tantas actividades que tendieron a degradarse) era más bien una excusa, un instrumento para fines de utilidad relativa. $Y$ el oro que podía aparecer hacia el final de un proceso por otra parte siempre reiniciado, no significaba otra cosa que la calidad de dicho proceso en el alquimista: fuera de él esa materia necesariamente limitada y a veces intratable se volvía la suma o la mezcla, un resultado como tantos. Y en el supuesto caso de relacionar esto con el arte, podría arriesgarse que también le concernía lo procesal, lo cíclico.

Una vez admitida la comparación lo primero que creí verificar fue esa misma pobreza de perspectivas concretas que hace a la poco garantizada razón de ser de una escritura. Aunque en este último caso con una primera condición que no puede saberse si era o no condición del alquimista: haber experimentado, con la mayor intensidad posible, la fatiga y hasta el rechazo de todo lo que entendemos por imaginario, de todo lo que está más allá de nuestra relación con una materia necesariamente limita: da por nosotros mismos.

Ganas repentinas de afirmar que la imaginación es esa rara facultad que estaría separándonos de lo único que nos concierne. Ganas de recurrir a un testimonio que hasta parecería inventado por venir del onirismo testimonial de Kafka: "Sin embargo, la vida natural para el hombre es la vida del hombre. Pero no nos damos cuenta. Nos negamos a verlo de esta forma. La vida humana es demasiado pesada; debido a esta causa queremos eludirla, por lo menos, en nuestra imaginación".

El oro por ninguna parte, para desaliento de los acreedores de confianza: nada que transmitirle a nadie, ni convicciones para representar, 
ni la menor idea de lo que irá a decirse porque es demasiado incierto lo que querria decirse y sobre todo porque seguirá en pie eso de que no estamos en condiciones de merecerlo, y que de ahí la escritura.

$\mathrm{Ni}$ personajes consecuentes, ni acciones que irán fatalmente a cumplirse: sólo pelo de un tío, caca de paloma, una uña de Quevedo, plomo, un andante, papel mojado en leche: materia palpable y hasta dócil, pero siempre amenazada de inutilidad. Ni siquiera motivos que nos justifiquen plenamente, ni iquiera un país que estaría pidiéndonos algo cercano a la maldición escolar de una conciencia histórica.

En última instancia contar siempre con todo esto, por obvio, pero atreverse a iniciar un impulso de "omisión" voluntaria: ausencia de valores inculcados donde sentimos y reconocernos pobres sin que intervenga el menor tipo de esfuerzo para ocultar esta pobreza. Mejor todavía: fomentando la verosimilitud ilimitada de su presencia.

Un movimiento desde algo menos garrafal (no dramático, no rencoroso) donde el gesto de escritura que conocimos pueda interrumpirse en una postura cómica que a su vez nos delata. Ninguna historia para nadie: el horror costosamente omitido de aquellos acuerdos. Entonces las -otras ganas de llamarle punto augural de una conjetura no libresca donde se admite la intuición (para con uno mismo, en el mejor de los casos) -de cierta contingencia inaferrable que sin embargo espera y a veces hasta confía en ese único punto de apoyo, cierta quietud augural. Digo quietud $y$ estoy diciendo la del bicho tenso que caza o se muere de hambre entre tantas certezas.

Si me detengo del fárrago, si lo detengo en mí, entonces una especie de hombre (en razón de edad, de desconcierto acumulado) puede concebir aquello único que le concierne: su ineptitud de recurrencia, los es. "casos metros cuadrados de una percepción irrisoria de lo que conforma su situación irrepetible. Por lo tanto el libro que alguna vez admitiria iniciarse no puede ser más que la reapertura de un periodo de pérdida, cuando ya toda memoria (de vida, de cultura) se queda sin nosotros por la simple razón de que empezamos a respirar otro aire, o a confirmar de que todavía no podemos. Enfoque que se reabre y hasta podría llegar a despojarnos de la veleidad de cierta posible participación activa.

La escritura abierta de que hablo, la escritura poemática, sólo admitiría partir de imágenes primarias (o elementales) que nada más aluden a lo impreciso, del presentimiento algo momentáneo de un ritmo que es an ir organizándose (reanudarse, invertirse) en la vacilación del contra. punto. Estado de disponibilidad que no se confirma sino en loş síntomas 
inconfundibles de tantas resistenciás: pálabras intratables con las que mantenemos otras tantas reservas, la pobreza que nos piden.

Escritura que se escribe a sí misma, libro convertido en la hitoria un tanto secreta de una voz sin transcurso organizado por la cultura (detención en un gesto cómico replegado sobre sí mismo): una voz que antes no teníamos y que tendería a arrebatarnos de la marejada de lo evidente; una voz preguntando a una vida que por supuesto no llevamos, que acaso no llevaremos nunca.

Nuestra vida que repta en la necesidad de un nuevo ciclo y la escritura responsable de recordarnos esa necesidad, esa perentoriedad.

A veces, por ráfagas, vuclvo a recuperar la certeza de que a partir de cierto punto no podrán eludirse dos riesgos también inverificables: que el propio proceso nos someta a una pérdida mayor de la prevista; que no podamos soportar la ansiedad de ese intrumento que nos pertenece y se nos escapa. Un párrafo sigue a otro párrafo pero entre ambos, en ese silencio todavia involuntatio y tal vez en una dirección ignorada, vuelve a generarse la misma impotencia para desentrañar (historia de pactos, de algo que no desearía perderse) la otra continuidad siempre esfumada $e$ impensable.

El momento de arranque de una escritura que lo tenga en cuenta sin resignarse del todo no sólo requiere ese pequeño conjunto de imágenes en apariencia irrelacionables más la inclinación hacia un ritmo que no se improvisa, sino la garantía de una incertidumbre previa y nunca resuelta, es decir prolongada, es decir que al mismo tiempo fue capaz de abarcarnos y ahora podria contener esa voz, transformarse en ella.

Prolongaciones $y$ vueltas hacia atrás que desbaratan toda dirección causal: primer motivo ( $y$ acaso el único verificable) donde puede justificarse que el poema necesite y a veces exija convertirse en aliento.

Me refieso a la suposición de ese ritmo originariamente contrapunteado al silencio voluntario de todo lo obvio, de tanta mentira con nos. otros mismos: si cuenta con algo (y lo vuelve condición de movimiento) es con ese inicio de virar interno que al mismo tiempo nos deja sin nada y nos vuelve posibles.

Porque mucho antes había sido aquel asomo de tensión que sobreviene al cansancio, ciertas lecturas que ni siquiera presentíamos y de repente son las únicas que lo señalan, reservas inútiles con un plazo más o menos fijo de resistencia, notas sueltas e inexpresivas, algo de vértigo, todo el desconcierto otra vez. $O$ sea que cabe volver atrás y atrincherarse, mezclarle 
razón a esa materia que nos pide todo y nada al mismo tiempo, o cabe verificar que ya es escritura.

Una escritura que nada más puede iniciarse cuando muchas de las cosas en las que todavía creíamos ya no nos alcanzan para vivir, y apenas para simular vivir. Pero que tampoco se iniciará alli mismo porque sobre todo depende de cierta paciencia de tensión: se cambia de ciudad o de cuadro en la pared, se escucha (acaso por algo) nada más que esa música, nos festejan (también por algo) un nuevo cumpleaños, reaparecen autores modernos en la Biblia. ¿Y la tensión aquella? Hasta cierto punto, o mejor hasta cierta página, mi vida o mis sospechas le dan a la escritura; después tendrá que ser ésta la que pida y me sirva secretamente de espejo.

$Y$ en el supuesto caso de que la tensión persista, todavía falta: falta convivir en silencio con esas imágenes inexplicables y augurales, falta estar completamente seguros de que la imaginación o la literatzra nunca podrian relacionarlas, falta llegar a la necesidad de ese tiempo futuro de escritura como único elemento capaz de desencadenar el proceso: único proceso capaz de mantenerme en este mundo, o en cualquier otro mundo.

Por eso debe resultar posible sorprenderse una segunda vez: ¿Queremos ser más pobres a partir de una actividad apenas entrevista en la que ni siquiera cabe la alternativa de sentirnos un poco trágicos?

Algo me consta y no contesta a nada: la única pauta de utilidad de un libro sólo puede ser corroborable en la experiencia misma: experiencia de escritura que paradójicamente necesita mi cambio (el desarrollo de la tensión inicial, el riesgo imponderable) y me pide ser mejor como hombre ¿me pide, de acuerdo a los días que corren, ser más ineficaz como escriba?

Toda moral establece uná determinada polaridad entre bien y mal, Lao Tse, por ejemplo, la reemplazaba por el par de lo "eficaz metafísicc" y de lo "vane". La utilidad de la novela en mí, otra vez, sería capaz de admitir una utilidad en el otro: todo lo equívoco, todo lo no explícito podría convertirse en el propio punto de fricción consigo mismo: cambio de actitud que podría originarse en él durante esa otra experiencia sin garantías que es o significa una lectura poemática concebida como silencio de lo que se sabe (y teme perderse) más la oportunidad de una "actividad" desilusionante. Nada más que lo que podemos saber como lectores, el resto se volvería preceptiva, o gesto dramático.

Sólo la experiencia de escritura interrelacionada con mi vida aquí y 
ahora es capaz de admitir todo incidente cotidiano, toda página ajena, todo momento imprevisible y su fractura como factores determinantes de una nueva dirección tampoco prevista en la primera página: el proceso me incluye como soy, no como supongo ser. Tanto puede suceder que la frase sea traida por un vendedor ambulante, como por el hijo de la portera: mi continuidad reside en escucharlos desde un sitio en mi que antes no estaba habilitado, que nunca lo estaría en caso de no trabajar con esa materia.

La novela de que hablo, ¿termina donde empezamos a parecernos otra vez a nosotros mismos? Termina, en todo caso, donde ya no volveríamos a escribirla, donde nos quedamos inmóviles hasta descubrir que esa inmovilidad puede ser la del hombre del bicho que caza.

$\mathrm{Y}$ lo cierto es que dentro de esta pobreza entrará despojarse también del prejuicio de vanguardia: zonas oscuras, onírico, fronteras de la ra. zón, automatismo: cualquiera suetña, está semiloco, asocia de la mañana a la noche, convive a su modo con ideas inconfesables. El "todo nos está permitido" es siempre gestual, urgencia por volverse el cuco de las tías como si esas tías $\longrightarrow$ estos "burgueses"- representaran la medida de algo, de algo que nos concierne.

Dije el gesto detenido en lo cómico y lo cierto es que su ambigüedad es demasiado grande, o a lo sumo tanto como la posibilidad siempre plausible de distraernos de nuestra propia estupidez y entonces irnos por el otro gesto destinado a espantar y a volvernos notorios.

Hubo días ( $y$ acaso no fueron neiesariamente los últimos), horas imprecisas de ciertos días sin pena ni gloria donde de pronto tuvo lugar la oleada tibia: ¿dónde estuve metido hasta hoy? Esa casi memoria impersonal de lo otro en medio de un mundo horizontal, opaco, siempre amenazado por el tedio y la imposibilidad de convertirlo en materia.

¿Memoria, en última instancia, de una alternativa que se va perdiendo?

Es indudable que volveré a la horizontalidad, sin darme cuenta de la caída, sin que nada ni nadie pueda venir a reprochármelo. Volveré, co. mo todo el mundo, a repetir viejas palabras organizadas para la derrota. Pero cabe la decisión de no volver a escribir.

Para volver a hacerlo habrá que fatigarse una vez más de uno mismo, concebir una manera distinta de salir de la cama, desearlo durante mucho tiempo hasta que llegue el momento de reconocerle unas pocas imágenes aparentemente irrelacionables que, en el supuesto caso de tener algo propio, sería esa imposibilidad interna de transformarse en símbolos. 
Tercera confesión casi inevitable: pensar una novela donde sucedan cosas interesantes, donde ambulen personajes y que a su vez digan cosas interesantes. Trabajar casi todos los días con ese material y su sintaxis, terminar un libro. Conoci gente que hace eso, gente pública, me asomé a sus vidas, los escuché hablar, tuve terror.

Barcelona

NÉSTOR SÁNCHEZ 